\title{
A Graça, o Sal e o Espírito ou José de Alencar Ao Correr da Pena
}

\author{
[ The Grace, The Salt, and The Spirit, or José de Alencar Ao Correr da Pena
}

\section{José Quintão de Oliveira ${ }^{\mathrm{I}}$}

RESUMO Importantes em si mesmos pelo valor literário, os folhetins de Ao Correr da Pena são também de importância definitiva para se compreender a evolução criativa do seu autor. Publicados em livro pela primeira vez em I874, foram bastante reeditados desde então, permanecendo, no entanto, escassamente estudados. Projeta-se analisar rapidamente essa produção ao mesmo tempo que se avalia sua circulação e se destaca o trabalho de alguns dos mais importantes estudiosos que atentaram ao folhetinismo de José de Alencar. - PalaVras-chaVE José de Alencar, folhetim, crônica, jornalismo e li- teratura. - ABSTRACT Of great importance due their literary value, the columns from Ao Correr da Pena are definitely important to understand the creative evolution of their Author. First collected on book in I874, despite republished many times since then, they remain scarcely studied. It intends to analyse these writings and simultaneously evaluate their circulation and excel the work of the more important of Alencar's newspaper production analysts. - KEYwords José de Alencar, columns, journalism and literature.

Recebido em 25 de abril de 2014

Aprovado em 28 de abril de $20 \mathrm{I} 4$

oliveira, José Quintão de. A Graça, o Sal e o Espírito ou José de Alencar Ao Correr da Pena. Revista do Instituto de Estudos Brasileiros, Brasil, n. 60, p. 77-90, abr. 2015.

DoI: http://dx.doi.org/Io.II606/issn.23I6-90IX.voi6op77-90

I Universidade de São Paulo (USP, São Paulo, SP, Brasil). 


\section{INTRODUÇÃO}

A atividade jornalística de José de Alencar teve início, pode-se dizer, ainda nos bancos acadêmicos quando participou da criação da revista Ensaios Literários em São Paulo. Essa publicação trouxe à luz pelo menos três escritos seus, o último deles em I850, de fundamental importância aos estudos da sua obra. Na condição de jornalista escreveu crônicas, romances-folhetins, ensaios políticos e literários, crítica teatral e literária e jornalismo político; foi colunista, redator, editor, diretor e dono de jornal. Polemista destemido enfrentou os poderosos do seu tempo e afrontou até mesmo sua majestade imperial em escritos desafiadores e desabridos. Praticou uma espécie de jornalismo de intervenção através das muitas cartas políticas que pôs em circulação como publicações autônomas em diversas séries, as mais importantes delas assinadas por Erasmo. Ao morrer, em dezembro de I877, estava envolvido com o jornal O Protesto, que editava em companhia do irmão Leonel e de Félix Ferreira. Resumindo, pode-se dizer que o escritor que foi também professor, publicista, político, folclorista, crítico literário entre outras muitas atividades, foi por toda sua vida jornalista. As páginas que seguem se voltam para uma pequena parcela dessa extensa produção e tratam dos rodapés que publicou no curto período de tempo transcorrido entre 3 de setembro de I854 e 25 de novembro de I855, em dois diferentes jornais da Corte - suas primícias literárias, no dizer de Pinto Coelho.

Quando Francisco Otaviano deixou a redação do Jornal do Comércio para assumir o Correio Mercantil, comprado pelo sogro, atendeu a gentil solicitação da direção da casa que lhe pedia indicação de um nome para substituí-lo no folhetim semanal oferecendo-lhes o nome do filho do senador José Martiniano de Alencar. A indicação foi educadamente anotada e ignorada. Os dirigentes do jornal queriam alguém mais experiente e de maior reconhecimento público; aquele espaço era importante demais para ser entregue a um desconhecido. Segundo Brito Broca, buscou-se "o estilo clássico, mesmo o grande talento, mas não se procurou o feitiço e o demônio inspirador dos vinte anos". Assim foram testados alguns medalhões - como Justiniano José da Rocha - , que fracassaram, levando o jornal a finalmente voltar a atenção ao indicado de Otaviano. Alencar relembra na polêmica com Nabuco que recebeu o convite do grande jornal, porém, "minha amizade pelo redator do Mercantil e o receio de lutar com ele na

2 BROCA, Brito. Românticos, Ultra-românticos e Pré-românticos. São Paulo, Polis, I979, p. 247. 
imprensa, induziram-me a declinar o honroso oferecimento do Jornal do Comércio e as vantagens que me faria, preferindo outro lugar de folhetinista em condições mais modestas"3.

Quando se afastou do jornal dirigido por Otaviano, foi novamente convidado para ocupar o espaço que já recusara e novamente o recusou.

\section{A FADA AO CORRER DA PENA}

Em 3 de setembro de I854, na metade inferior da capa do Correio Mercantil, o folhetinista se dirige aos leitores e às leitoras propondo-se a lhes contar uma história:

O título que leva este artigo me lembra um conto de fada que se passou não há muito tempo, e que desejo contar por muitas razões; porque acho-o interessante, porque me livra dos embaraços de um começo, e me tira de uma grande dificuldade, dispensandome da explicação que de qualquer modo seria obrigado a dar. Há de haver muita gente que não acreditará no meu conto fantástico, mas isto me é indiferente, convencido como estou de que escritos ao correr da pena são para serem lidos ao correr dos olhos. ${ }^{4}$

Assim, despretensiosamente, inicia José de Alencar a sua carreira de folhetinista, conversando com seu leitor e sua leitora (especialmente esta), com jeito de moço tímido que começa fingindo que não começa: "Um belo dia, não sei de que ano, uma linda fada, que chamareis como quiserdes, a poesia ou a imaginação"`. Os leitores do folhetinista já sabem como prossegue a historieta, não se roubará o prazer da descoberta aos ainda não leitores. Devem ser destacados nesse início de carreira a prosa leve e descontraída, o também descontraído modo de conversar com o leitor, como que intentando prendê-lo com o seu aparente descompromisso para conduzi-lo pela mesma forma aparentemente descompromissada aos temas sérios de que muitas vezes tratará.

No folhetim de 4 de março de I855 imagina o exame de consciência de uma moçoila pura e inocente (são puras e inocentes as moçoilas românticas), que busca nas partes mais profundas da alma algum pecadinho que a faça ficar com as faces cor de... "Arrependi-me! Não digo a cor. Reflitam e adivinhem se quiserem. Tenham ao menos algum trabalho em lerem, assim como eu tenho em escrever"6.

As reticências e o apelo mais que direto ao leitor apenas tornam ainda mais explícita essa característica do folhetinista, que o acompanha desde o início. Na verdade, uma conversa que vai bem além do dono da casa, envolvendo também a mulher, as filhas casadoiras (como já se disse e se quer enfatizar) e quem mais seja. Todos participam. O texto é sempre, porém, um cavaquear descompromissado, livre para falar dos mais variados assuntos, dos mais fúteis aos mais graves. Nessa cavaqueira, durante mais

3 ALENCAR, José de. A Polêmica Alencar-Nabuco. Org. de Afrânio Coutinho. Rio de Janeiro, Tempo Brasileiro, I965, p. 79.

4 Idem, José de. Ao Correr da Pena. Org. de João Roberto Faria. São Paulo, Martins Fontes, 2004, p. 5.

5 Idem, p. 6.

6 Idem, p. 238. 
de ano Alencar afia a sua pena, conquista notoriedade e inicia um diálogo que até hoje prossegue. $\mathrm{O}$ folhetinista, como o escritor, como o político, prezará sempre a conversa, o que poderá ser visto, por exemplo, na sua intervenção no debate parlamentar em I870, quando se dirige ao presidente afirmando: "Vou, Sr. Presidente, conversar com V. Exa . a respeito das questões de que me vou ocupar". Em seguida afirma que o termo está consagrado no debate parlamentar e insiste no seu uso; confirmando assim as escolhas que vinham desde o tempo dos pés de página do Correio.

O ficcionista está em formação nos labores semanais do folhetinista - a linguagem é leve, brincalhona e há muita metalinguagem. Chama também a atenção, além dessas características e do tom de conversa, a mistura de gêneros, que une a poesia à narrativa, passando pelas cartas e pela crônica histórica; saltando da sátira ao jornalismo político; testando a crítica teatral e musical e o fait divers. A pena passeia sobre o papel, descomprometida, livre e inventiva, como a fada a que o novel escritor a compara. Observe-se o trecho que segue:

Muitas vezes faltavam-nos as imagens. Seria necessário recorrer a todas as artes, materializar o som, colorir a voz, dar corpo à música, para descrever todas as belezas desse canto inspirado.

Assim há umas notas que chamejam, irradiam como chispas brilhantes lançadas no ar; há outras que caem docemente como gota de orvalho da manhã. Umas são brilhantes que desferem raios de luz; outras são flores que exalam perfumes à noite.

Muitas sorriem, brincam com os lábios, aninham-se nas covinhas da boca, fazem mil travessuras, furtam um beijo - e fogem. Algumas suspiram, tremem, vacilam como a lágrima que se desfia pelas faces, palpitam como um seio oprimido, e por fim vêm expirar suavemente dentro d'alma.

Às vezes dir-se-ia que o beija-flor se aninha no cálice de uma rosa; outras que bate as suas asas douradas e se lança no espaço, colorindo-se nos raios do sol.

E todos esses arabescos e fantasias brilhantes que vos traça a imaginação, todas essas flores mimosas, esses raios de luz e esses lindos coloridos, não valem o drama cheio de emoções que se passa em vossa alma aos sons daquela voz harmoniosa. ${ }^{8}$

Tudo isso para falar "daquela voz harmoniosa", isto é, a cantora Charton. Essa vontade de brincar, de experimentar, de explorar as dimensões lúdicas da linguagem é uma das marcas mais fortes desse folhetinista. $O$ folhetim seguinte àquele de que foi retirado - 6 de maio de I855 - o trecho supra foi quase todo preenchido por esse jogo descompromissado com a linguagem. Partindo de uma visita a um estabelecimento - armazém, na linguagem da época - ótico, Alencar solta a palavra que esvoaça e brinca liberada e folgazã, mais uma vez fada que se faz pluma.

7 Idem, Discursos Parlamentares. Brasília, Câmara dos Deputados, I977, p. 2 I.

8 Idem, Ao Correr da Pena, op. cit., 2004, p. 296. 
Algumas outras características da escrita do jornalista em início de carreira devem ser também observadas. Primeiro, espanta como desde o primeiro dia se apresenta segura e bastante definida nos aspectos do estilo e no domínio das técnicas da expressão posta em letra. O que talvez se explique parcialmente pela condição de leitor e anotador voraz que o acompanha desde a infância e pelo fato de haver começado a publicar, ainda que esparsamente, desde I848. Há ainda o aspecto lúdico da linguagem mostrado anteriormente, que se manifesta não só no jogo da imagem e da figuração, também no uso do trocadilho - ou calembur, como diz o escritor - , na constante presença dos provérbios e ditos populares; no uso quase que obsessivo dos termos de e no permanente exercício da metalinguagem. Observando esses aspectos da linguagem do jornalista seria interessante considerar a ideia da sua adequação, como o faz Freixeiro9 quando trata da polêmica sobre o poema de Gonçalves de Magalhães. Ou seja, Alencar se serve de uma linguagem que responde às necessidades da escrita do folhetim, feita ao correr da pena. Quando transitar para a prosa literária da ficção o bem escrever terá outro sentido, respondendo às diferenciadas demandas no trato com a palavra impostas pela literatura.

Resumidamente, o avanço da posição de defensor da pureza da língua - saliente num texto de $1850^{\text {Io }}$ e que mais tarde tanto combaterá - à condição de escritor que "gosta do progresso em tudo, até mesmo na língua que fala" Progressismo que o leva a defender não só os termos de origem estrangeira, também os neologismos e os brasileirismos em geral, sempre balizados pela noção de adequação, conveniência e elegância de expressão. Deve-se acrescentar que na verdade sua concepção de língua aparece já madura bem antes desse prefácio, como se salienta nos folhetins e nas cartas a respeito do poema de Gonçalves de Magalhães, em que descreve a língua portuguesa como uma "sonora e doce filha dos romanos poetizada pelos árabes e pelos godos" ${ }^{\text {ז2 }}$.

O que espanta num cotejo entre o texto de I850 e um outro da maturidade literária do autor, mais que a mudança, é a continuidade. É difícil se imaginar como pôde um estudante de vinte anos ter acumulado uma tão sólida reflexão sobre a língua e a literatura. Desde o uso idiossincrático da pontuação (expurgado posteriormente do abuso no emprego do travessão, que, aliás, lembra Fenimore Cooper) à ojeriza ao uso do artigo definido, está lá o Alencar de I872 plenamente contido no ensaísta que publica os primeiros textos. Estão lá também o mesmo gosto pela frase sonora, a exploração do ritmo e da eufonia dos vocábulos, tangenciando e muitas vezes tocando o lúdico e o musical, que caracterizam o escritor maduro.

O mesmo combate aos chamados classicistas, isto é, aqueles que defendiam uma linguagem literária brasileira submissa ao cânone coimbrão, que marca o pós-escrito a Diva está já no escrito precoce; também a mesma defesa de uma linguagem literária

9 FREIXEIRO, Fábio. Alencar: Os Bastidores e a Posteridade. Rio de Janeiro, Museu Histórico Nacional, I977. Io Referência à última das três publicações do período acadêmico do escritor, O Estilo na Literatura Brasileira, saída na revista Ensaios Literários, dos estudantes de Direito de São Paulo em I850, incluído como apêndice em livro: MARCO, Valéria de. O Império da Cortesã. São Paulo, Martins Fontes, I986, p. 20I-204. II ALENCAR, José de. Diva. Rio de Janeiro, José Olympio, I95I, p. 3II.

I2 Idem, Cartas sobre A Confederação dos Tamoios. Rio de Janeiro, Empresa Nacional do Diário, I856, p. 52. 
brasileira, sintonizada com o tempo e o meio. Está lá também a consequente ideia de adequação da linguagem já referida, isto é, a concepção de uma unidade entre a forma e o conteúdo, diferenciando-se em consequência o estilo conforme se diferencia o assunto tratado. Assim, um tema quinhentista requererá uma linguagem adequada ao século XVI, isto é, uma linguagem quinhentista. Mas como usar tal linguagem para falar dos temas atuais? Como usá-la para falar dos salões fluminenses ou do sertanejo? Soaria caricato.

Devem ser destacados ainda o amor aos clássicos, o sistemático cotejo com o que dizem aqueles grandes autores antigos ou modernos que o escritor considera merecedores de admiração e em quem reconhece autoridade nos temas linguísticos e literários. Nessa condição são evocados, entre outros, Antônio Feliciano de Castilho, Almeida Garrett e Alexandre Herculano em I850; o mesmo Herculano no prefácio a Sonhos d'Ouro e o dicionarista Morais no pós-escrito a Diva. Esse gosto se associa ao estudo sistemático da língua e da literatura, a busca do conhecimento do passado, numa aparente antecipação do escritor no estudante aplicado. Tem-se a impressão de que o jovem Alencar, mais que simplesmente a estudar e fruir os clássicos, buscou-os como uma tarefa afeita a quem se prepara para os afazeres do escritor.

Uma análise mais exaustiva do ensaio da época acadêmica, ponto por ponto cotejado com a maturidade do escritor, mostraria acima de tudo essa coerência, essa continuidade entre dois momentos tão distintos da sua trajetória. Houve mudanças, como já se observou. Do ponto de vista das posições assumidas face à língua e à literatura, isto é, do ponto de vista literário, seria, porém, mais adequado falar em amadurecimento; ou progresso, para se usar o termo caro ao escritor. A partir desse "O Estilo na Literatura Brasileira" se compreende a afirmação da condição de escritor inserida nos folhetins de Ao Correr da Pena, que deixa de ser pretensão para se mostrar como o que realmente é, resultado de estudo e prolongada reflexão; o folhetinista se expressa refletidamente convencido da sua escrita e da própria capacidade para o exercício das letras. Da mesma forma a reivindicação da condição de folhetinista feita pelo escritor maduro no prefácio a Sonhos d'Ouro não é mais um exercício de modéstia intelectual. Torna-se coerente reafirmação de uma condição precocemente atingida, equalizando o folhetinista que ainda não produziu e o romancista que escreve amparado por uma obra extensa e reconhecida. São os marcos de uma jornada precocemente antevista e iniciada.

\section{O MODO DO FOLHETINISTA}

Aquele modo de tudo falar tão descompromissadamente tem um certo compromisso com a isenção, surpreendente num período de tanto partidarismo: "Simples investigadores, podemos apreciar o fato com a calma necessária, sem sermos influenciados por interesses pessoais" ${ }^{\text {ㄱ. }}$. E assim, procura falar de quase tudo com certo distanciamento. Percebe-se o gosto pela música, pelo teatro, o protesto contra o bacharelismo, acompanhados às vezes da galhofa, às vezes da pura brincadeira. Há

I3 Idem, Ao Correr da Pena, op. cit., 2004, p. 4I3. 
também junto a essa muita graça, muita leveza, o quantum satis de ironia. Mas seja numa disputa entre dilletanti ou numa crise ministerial, há sempre a preocupação com o outro lado, uma espécie de busca de uma compreensão distanciada.

Num folhetim fala da renovação do Passeio Público e outros melhoramentos da cidade e reivindica a instalação de "repuxos e jets d'eau", para em seguida exclamar:

Ai! Lá me caiu a palavra do bico da pena. Nada; vamos tratar de nacionalizar a língua; um correspondente do Correio Mercantil de segunda-feira reclama de nós este importante serviço.

Mas que quer dizer nacionalizar a língua portuguesa? Será misturá-la com a tupi? Ou será dizer em português aquilo que é intraduzível, e que tem um cunho particular nas línguas estrangeiras? ${ }^{\text {T4 }}$

E por aí prossegue, em tom irônico e brincalhão a inquirir o missivista, de quem não se sabe se reivindica a nacionalização da língua a Alencar em particular ou a todos que escrevem nos jornais. O motivo da língua literária brasileira tão caro ao autor d'O Guarani e de Iracema comparece assim em clave irônica, perguntando se se dirá cortado por coupé etc., muito longe ainda da gravidade e importância que lhe dará o ficcionista. Sem, no entanto, esclareça-se, ignorar a importância da questão apresentada pelo leitor. Parece uma forma de definir que ao se propor a questão, o escritor o fará de maneira refletida e madura. Enfrentará, então, um problema capital para o estabelecimento de uma literatura brasileira diferenciada da portuguesa pelo tema, pela linguagem e também por se vincular a uma tradição específica que, se partilha pontos com a tradição lusitana, também dela difere caracteristicamente.

Nas páginas do jornal, ao correr da pena, nasce, além do escritor, o polemista. Esse debate com o leitor se junta a vários outros que aparecem nos folhetins e lembra também outras das fortes características do escritor maduro: a disposição e, parece mesmo o gosto, para a polêmica, como o Brasil em breve descobriria a partir de meados do ano seguinte nas cartas de Ig em torno do poema A Confederação dos Tamoios, de Domingos José Gonçalves de Magalhães. Num folhetim reclama de um surpreendente homônimo seu que comparece entre os colaboradores de um novo jornal que se lança à circulação. Parece que o jornalista já se tornara definitivamente uma figura pública, usando-se o seu nome como chamariz para a nova publicação. Antecipa também uma das batalhas do escritor maduro, como se vê em Como e Porque Sou Romancista, em combate contra o indevido uso do seu nome e na defesa da sua obra, vítima de falsificações e edições clandestinas.

A curta vida do folhetinista Alencar se apresenta dividida em duas partes, a primeira corresponde ao período em que escreveu no Correio Mercantil, onde chegou a convite do amigo Francisco Otaviano que o dirigia, como já se disse. Não se intentando dilatar em excesso o espaço dedicado a tão curto tempo, seria, porém importante destacar a sua saída desse jornal. Ocorre que na crônica de 7 de julho de I855, como sempre se dava, voejou sobre os mais variados assuntos, mas tratou também da febre

I4 Idem, p. 2I6-2I7. 
especulativa que assolava a Corte, e, por extensão, o país, à época. E encaminha essa parte do folhetim para o seu encerramento com os parágrafos que seguem:

Dantes os homens tinham as suas ações na alma e no coração; agora têm-nas no bolso ou na carteira. Por isso naquele tempo se premiavam, ao passo que atualmente se compram.

Outrora eram escritas em feitos brilhantes nas páginas da história, ou da crônica gloriosa de um país; hoje são escritas num pedaço de papel dado por uma comissão de cinco membros.

Aquelas ações do tempo antigo eram avaliadas pela consciência, espécie de cadinho que já caiu em desuso; as de hoje são cotadas na praça e apreciadas conforme o juro e interesse que prometem. ${ }^{\text {I5 }}$

Encaminha apenas, porque não há um encerramento, neste ponto o texto aparece interrompido por linhas pontilhadas. Segundo observa Francisco de Assis Barbosa, indicadoras da intervenção da direção do jornal sobre o texto do escritor ${ }^{16}$, que ficou assim mutilado, como percebe o leitor e percebeu o autor. Vendo sua palavra censurada Alencar protestou, como se confirma na carta por ele dirigida à Redação do Correio Mercantil e ao colega e amigo Francisco Otaviano:

Tendo saído inteiramente estropiado o meu artigo de hoje, é necessário que eu declare o motivo por que entendi não dever continuar a publicação da "revista semanal" dessa folha, visto como desapareceram algumas frases que o indicavam claramente.

Sempre entendi que a "revista semanal" de uma folha é independente e não tem solidariedade com o pensamento geral da redação; principalmente quando o escritor costuma tomar a responsabilidade de seus artigos, assinando-os.

A redação do Correio Mercantil é de opinião contrária; e por isso, não sendo conveniente que eu continuasse "a hostilizar os seus amigos", resolvi acabar com o Correr da pena, para não comprometê-la gravemente.

Antes de concluir, peço-lhe que tenha a bondade de fazer cessar o título com que escrevi as minhas revistas. Não tem merecimento algum, há muitos outros melhores: mas é meu filho ${ }^{\text {I7 }}$, e por isso reclamo-o para mim, mesmo porque talvez me resolva mais tarde a continuá-lo em qualquer outro jornal que me queira dar um pequeno canto.

I5 Idem, p. 408-409.

I6 BARBOSA, Francisco de Assis. José de Alencar Cronista do Primeiro Encilhamento. In: Achados do

Vento. Rio de Janeiro, INL, I958, p. II9-I28.

I7 Lembre-se neste ponto o prefácio de Sonhos d'Ouro - Bênção paterna - e o hábito do escritor maduro, apontado pelos críticos, de considerar suas obras como filhos que o pai zeloso se empenha em proteger. 
Agradeço-lhe infinitamente as expressões delicadas que me dirige, e que não mereço. $\mathrm{O}$ Correio Mercantil nada me deve: sou eu ao contrário que lhe devo o ter honrado os meus obscuros artigos admitindo-os nas suas colunas entre tantas produções brilhantes, entre tantas distintas inteligências. ${ }^{18}$

Francisco de Assis Barbosa supõe que esses amigos do Correio Mercantil fossem "os dirigentes das companhias ou os que, dentro do governo, cruzavam os braços à agiotagem e à especulação" ז9. Talvez estes e mais alguns maganos poderosos que lucravam com a febre especulativa. Deve ser anotado que a carta foi publicada pelo jornal no dia seguinte, precedida de uma nota curta e respeitosa, conforme se vê na reprodução que delas fez Pinto Coelho no apêndice da sua edição de Ao Correr da Pena:

A seguinte carta nos foi remetida pelo Sr. Dr. Alencar. O nosso colega estava em seu pleno direito escrevendo-a.

Não temos a menor observação a fazer sobre o seu conteúdo.

Há, porém, nela uma recomendação que tornava-se desnecessária. Quando não fosse por outro princípio, a delicadeza nos levaria a não usarmos do título dos artigos do colega para darmos valor e merecimento aos nossos. ${ }^{20}$

Parece justificar a reprodução completa da nota acima o fato de ser quase que totalmente ignorada pelos estudiosos de Alencar, que raramente ou nunca a mencionam. Deve ser registrado que nesse aspecto o jornal que começou tão mal se saiu com certo garbo, o que não reduz a mácula deixada pela censura ao seu colaborador. Outro ponto não bem esclarecido é o seguinte: a coluna termina com uma despedida do jornalista, que informa aos leitores que está se separando da pena de folhetinista talvez para sempre. Ou seja, o trecho indigitado foi, provavelmente, analisado pela direção do jornal que tentou negociar com Alencar a sua supressão. Esse não concordou e se demitiu, entendendo que seu trabalho seria respeitado, o que não ocorreu. $O$ que fica acima de tudo nesse episódio é a altanaria do escritor que ao ver desrespeitada sua liberdade, de forma exemplar e incontinenti se demite ${ }^{2 \pi}$. Paga o preço de se ver privado de tão importante espaço (o Correio Mercantil era então um dos mais importantes e respeitados jornais do país) e provavelmente ver abaladas as relações com o amigo estimado. Na polêmica com Joaquim Nabuco o escritor reitera que deixou o jornal porque teve desrespeitada a sua liberdade ${ }^{22}$.

I8 ALENCAR, José de. Ao Correr da Pena. São Paulo, Melhoramentos, I955, p. I9.

I9 BARBOSA, Francisco de Assis, op. cit., I958, p. I26.

20 Correio Mercantil. In: ALENCAR, José de. Ao Correr da Pena. São Paulo, Typ. Allemã, I874, p. 309.

2I Num melindre em que Cavalcanti Proença aponta "muita dignidade profissional e intelectual”, ver PROENÇA, M. Cavalcanti. José de Alencar na Literatura Brasileira. Rio de Janeiro, Civilização Brasileira, I965, p. Io. 22 ALENCAR, José de, A Polêmica Alencar-Nabuco, op. cit., I965. p. 78. 
Existem coisas de que não se abre mão, ensina o jornalista que, muitos anos depois, em 5 de agosto de I87I, afirmará da tribuna do parlamento: "sou filho da Imprensa; a ela devo o pouco que valho"23. Valia muito mais, como confirma a obra e antecipa o gesto. De toda forma deve ficar registrada a condição de intransigente defensor da liberdade de imprensa como característica de toda a carreira do escritor.

Tempo virá em que do obscuro gabinete do escritor a pena governará o mundo, como a espada de Napoleão da sua barraca de campanha.

Uma palavra que cair do bico de uma pena, daí a uma hora correrá o universo por uma rede imensa de caminhos de ferros e de barcos de vapor, falando por milhões de bocas, reproduzindo-se infinitamente como as folhas de uma grande árvore.

Esta árvore é a liberdade; a liberdade de imprensa, que há de existir sempre, porque é a liberdade do pensamento e da consciência, sem a qual o homem não existe; porque é o direito de queixa e de defesa, que não se pode recusar a ninguém. ${ }^{24}$

São palavras de Ao Correr da Pena e uma espécie de mandamento ético do jornalista que, depois de pela segunda vez recusar o convite do Jornal do Comércio para redigir seus folhetins, voltaria ao jornalismo em posição de maior destaque, como diretor-gerente (responsável pela redação e administração) do Diário do Rio de Janeiro. Demonstrando a importância que dava ao folhetim, reiniciou imediatamente a publicação do seu Ao Correr da Pena, que circulou por mais sete vezes. Aliás, é interessante observar como o folhetinista que fala a todos vai aos poucos mudando seu público preferencial e se dirige cada vez mais à mulher. Na última coluna publicada no Correio Mercantil diz a certo momento: "E agora atirai o jornal de lado, ou antes passai-o ao vosso marido, ao vosso pai ou ao vosso titio, para que ele leia o resto"25. Ou seja, primeiro a leitora, depois os demais leitores. É provável que os temas da política e da economia, tão importantes a princípio, se tornam secundários na medida em que o escritor alcança outras tribunas além do folhetim. Da mesma forma que ocorre uma opção preferencial pelo público feminino, ocorre também uma como que feminilização da sua prosa, bastante saliente nas últimas crônicas. Esses dois fenômenos parecem bastante evidentes exatamente nesses últimos escritos do gênero que antecedem a 25 de novembro de I855, quando se calou definitivamente o folhetinista ${ }^{26}$ que tinha, afinal, à sua espera tarefas muito mais importantes que cumprir. De toda forma, parece interessante registrar a ocorrência para se perguntar se não estaria ali, naquela prosa tão feminina - crisálida pronta a se romper - o romancista que tão de perto falará ao coração feminino em A Viuvinha e Cinco Minutos que começariam a surgir no ano seguinte.

23 Idem, Discursos Parlamentares, op. cit., I977. p. 627.

24 Idem, Ao Correr da Pena, op. cit., 2004, p. 35I-352.

25 Idem, p. 4I2.

26 É provável que o escritor tenha escrito e publicado outros folhetins (para afirmá-lo definitivamente seria necessário um estudo até agora não realizado), porém, demonstrando a pouca importância que passava a dar ao gênero, esse pai tão empenhado na defesa do s seus filhos literários, sequer os assina. 


\section{DO JORNAL AO LIVRO}

Deve-se registrar que essas sete colunas finais não foram, então, recolhidas em livro. A primeira edição de Ao Correr da Pena circulou em I874, organizada e prefaciada por José Maria Vaz Pinto Coelho com autorização do autor ${ }^{27}$. Na folha de rosto está identificado o impressor: Typ. Allemã (Tipografia Alemã) e a data. Essa edição foi feita às expensas do editor, isto é, de Pinto Coelho, que promete no final do volume publicar em um futuro livro os nomes dos subscritores cotistas que colaboraram para torná-la possível. O certo é que era grande admirador do escritor e soube cedo reconhecer a importância dos seus folhetins: "Foi com eles que o seu autor abriu as portas da república das letras, onde por vias as mais legitimas não tardou a chegar à soberania, sem nenhumas maioridades antecipadas." ${ }^{28}$ - O que serão maioridades antecipadas? Uma referência à anedota sobre o episódio envolvendo o Imperador e Alencar relativamente à senatoria pelo Ceará? - O simples fato de transpor os folhetins para o livro, garantindo-lhes a sobrevida para além das páginas do jornal já constitui um movimento crítico e importante contribuição à literatura brasileira. Sua edição reúne, ainda, extensa fortuna crítica nas páginas de abertura e se fecha por um índice detalhado, com o sumário de cada capítulo, que se tornaria parte do livro.

José Maria Vaz Pinto Coelho da Cunha é o nome completo desse admirador de Alencar. Nasceu em Sabará, Minas Gerais, em I836, e estudou Direito em São Paulo; foi juiz na Paraíba e era dado às letras, tendo deixado inúmeros livros, ensaios e escritos diversos sobre os mais variados assuntos. Publicou também inúmeros trabalhos sobre sua área de atuação e foi tradutor. Sacramento Blake dedicou-lhe um verbete do seu Dicionário Biográfico. Pedro Nava o dá como primo e a ele se refere em ao menos três diferentes passos do seu Baú de Ossos.

Deve ser anotado que tanto a edição preparada por Pinto Coelho como a segunda, de I888, com o selo do livreiro B. L. Garnier, editada sob a responsabilidade do filho do escritor, Mário de Alencar, reproduziram apenas a primeira fase dos folhetins de José de Alencar, saída no jornal dirigido por Otaviano. Em I899, já com o selo H. Garnier circulou uma nova edição, provavelmente a terceira, última do século XIX, perfazendo ao menos duas edições por esse editor. Em I938, os folhetins foram impressos com o selo da Livraria Editora Record, esta é talvez a quarta edição; dela se falará à frente. A edição completa do folhetinismo do autor de Ubirajara teria de aguardar até I956, quando a organizou e publicou Francisco de Assis Barbosa, tendo como prefácio seu texto supracitado. Essa edição foi reimpressa ao menos três vezes - em I958 como segunda edição e, posteriormente, alcançando quatro reimpressões até I96I. A obra completa do escritor lançada pela Aguilar a partir de I959 também inclui os folhetins. Essa edição está fotograficamente reproduzida no primeiro volume do Teatro Completo de José de Alencar, editado pelo Serviço Nacional de Teatro, em I977. A Tecnoprint (hoje Ediouro) editou, em I968, com uma nota biográfica de M. Cavalcanti Proença, introdução de Afrânio Coutinho, ilustrações de Luís Jardim e o título de Crônicas da Coluna Ao correr da pena.

27 Disponível na Brasiliana USP: 〈http://goo.gl/FcmXrQ〉.

28 COELHO, José Maria Vaz Pinto. Declaração. In: Alencar, José de. op. cit., I874, p. XLV-XLVI e p. XLVI. 
Em coleções apresentadas como obras completas ou selecionadas de José de Alencar, circulou pelas editoras Difusão Literária, Edigraf (pelo menos duas edições), Formar, Instituto de Divulgação Cultural, LER (a já mencionada Livraria Editora Record), Letras e Artes, Literart e Piratininga. Essas coleções eram normalmente destinadas à venda de porta em porta e foram muito populares no país durante um largo período, a partir dos anos de I930 chegando até os anos de I990. Desse tipo de edição certamente haverá outras ainda não identificadas pela pesquisa. Deve ser registrado também que essas coleções costumavam ser reimpressas, muitas vezes sem data e sem identificação da edição, havendo mesmo algumas em que não se identifica sequer o editor.

Da lista supra deve ser destacada a edição LER, que circulou em I938 em versões encadernadas e também em brochura, com o estranhíssimo título de Páginas Avulsas, em uma coleção da ficção de Alencar espalhada por extensos 3I volumes, destinados à venda em 22 prestações de 20 mil-réis, informa Hallewell. Segundo esse estudioso, essa edição da obra do escritor cearense marca a entrada de uma empresa brasileira no mercado da venda de livros porta a porta, explorado pela firma americana W. M. Jackson desde I9II ${ }^{29}$. Não há informação sobre o motivo para a alteração do título da obra, o que termina por deixar a impressão de que não teria outra intenção além de enganar o leitor, induzindo-o a comprar um livro que supõe ser novidade. Não parece ser diferente o que se deu em I970, quando o Clube do Livro - empresa de venda de livros por assinatura, modalidade em que $\mathrm{o}$ assinante recebe mensalmente um volume editado para o mês - lançou uma antologia desses folhetins com o título de A Pena de Ouro. O volume recolhe apenas as crônicas saídas no Correio Mercantil; estranhamente a última delas está substituída por um longo trecho do romance As Minas de Prata. É seguramente uma das piores edições dadas aos folhetins do escritor.

Já em outro nível, devem ser mencionadas as duas antologias preparadas por João Roberto Faria, a primeira, de I995, para o jornal Folha de S. Paulo com selo da editora Ática e a segunda para a Global, nas coleções de obras escolhidas dessa editora. O mesmo pesquisador organizou para a Martins Fontes a edição de Ao Correr da Pena, cuidadosamente revista e com um estudo introdutório. Ao se tratar da circulação do folhetinismo de Alencar deve ser mencionada, ainda, a especialmente famosa parte inicial do folhetim de 22 de outubro de I854, sobre a volta de Monte Alverne ao púlpito, incluída em incontáveis antologias.

Esse recenseamento das edições dos rodapés dominicais do escritor quer apenas destacar a sua larga circulação, apontando-os como uma parte da sua obra merecedora de ser mais estudada. Intenta-se também chamar a atenção para aqueles que o têm feito, como João Roberto Faria que tanto do seu tempo dedicou a esses escritos. $\mathrm{Na}$ introdução que escreveu para a edição de $2004^{30}$, estabelece um diálogo que parte de Alencar, passa por Vaz Pinto Coelho e chega a Francisco de Assis Barbosa, reunindo assim ao autor os olhares que mais acuradamente atentaram à obra produzida ao correr da pena. Ali, destaca o folhetinista na sua condição de testemunha da história

29 HALLEWELL, Laurence. O Livro no Brasil: Sua História. Tradução de Maria da Penha Villalobos; Lólio Lourenço de Oliveira \& Gerson Geraldo de Souza. São Paulo, Edusp, 2005.

30 FARIA, João Roberto. O Rio de Janeiro de I854 e I855. In: ALENCAR, José de, Idem, Ao Correr da Pena, op. cit., 2004, op. cit., 2004, p. XI-XXXIII. 
nos seus desdobramentos cotidianos: as mudanças urbanas, as novas formas de socialização geradas por essas mudanças que o país sofria. Aparece assim um Alencar progressista e envolvido com a vida cultural e artística da Corte, retratando-a e se empenhando em favor do seu adequado desenvolvimento e capaz de festejar "a grande regeneração que devemos os esforços do Sr. Eusébio de Queirós”포. Isto é, a lei que leva o nome desse político e definitivamente baniu o tráfico negreiro da África para o Brasil. Essa preocupação com o desenvolvimento, com o progresso, seja da sociedade seja das letras, se mostrará uma característica marcante do escritor e do cidadão e deve ser apontada nesse momento da sua trajetória para ser compreendida na sua inteireza. Este ensaio não trata das produções posteriores de Alencar, particularmente da sua ficção; deve-se enfatizar, porém que seus escritos ao correr da pena de maneira alguma abonam a moldura de conservador e mesmo reacionário em que parte da crítica, a partir da polêmica com Joaquim Nabuco, insiste em enquadrar o escritor.

Encaminhando-se para o crepúsculo dos seus folhetins, o autor de Ao Correr da Pena mostra o espírito polêmico e a independência de caráter tão desassombradamente seus. Mostra também que já dominava a forma do romance, que "não é qualquer coisa, é uma história dividida em capítulos, que principia rindo e acaba chorando, ou vice-versa; e na qual devem entrar necessariamente um namorado, uma moça bonita, um homem mau, e diversas outras figurinhas de menos importância"32.

Aqui se lembra Garrett, desde o já referido "O Estilo na Literatura Brasileira”, de I85033, chamado entre os grandes, também possuidor da fórmula do romance, da qual também oferecera sua receita ${ }^{34}$. Como se constata, Alencar diferentemente do mestre não se limita aos ingredientes, inclui também o modo de prepará-la. E dela se servindo fará romances e dramas com mais e menos ingredientes, sempre, porém, com um tempero - o escritor certamente preferiria sainete -todo seu. Essa receita já vinha, porém, se formando desde muito antes do surgimento do folhetinista, como o autor registra nas páginas de Como e Porque Sou Romancista. Assim se observa que ao correr da pena se formou o escritor; cristalizou-se o jornalista e se armou o espírito do crítico literário e do romancista, como se começará a descobrir no ano seguinte, nos escritos sobre a obra de Gonçalves de Magalhães e nos primeiros ensaios de romance-Cinco Minutos e A Viuvinha - preâmbulos de uma obra-prima: O Guarani, que virá logo em seguida.

3I ALENCAR, José de, Ao Correr da Pena, op. cit., 2004, p. 378.

32 Idem, p. 45 I.

33 Cf. nota 9.

34 "Todo drama e todo romance precisa de:/Uma ou duas damas,/Um pai,/Dois ou três filhos, de dezenove a trinta anos,/Um criado velho, Um monstro, encarregado de fazer as maldades,/Vários tratantes e algumas pessoas capazes para intermediários." GARRETT, Almeida. Viagens na Minha Terra. Porto, Figueirinhas, I958, p. 26. 
SOBRE O AUTOR

JOSÉ QUINTÃo DE OLIVEIRA Professor de Literatura Brasileira, pós-doutorando em Literatura Brasileira no Instituto de Estudos Brasileiros da Universidade de São Paulo. Bolsista da Fapesp, desenvolve um projeto de estudo sobre a obra de José de Alencar com a supervisão acadêmica da Profa. Dra. Telê Porto Ancona Lopez. E-mail: jqjojqo@yahoo.com.br

\section{REFERÊNCIAS BIBLIOGRÁFICAS}

ALENCAR, José de. A Polêmica Alencar-Nabuco. Org. de Afrânio Coutinho. Rio de Janeiro, Tempo Brasileiro, I965. . Ao Correr da Pena. Organização de João Roberto Faria. São Paulo, Martins Fontes, 2004. . Ao Correr da Penna. São Paulo, Typ. Allemã, 1874. Disponível em: 〈http://goo.gl/FcmXrQ〉. Acesso em: I3 dez. 2014. . Ao Correr da Pena. Org. por Francisco de Assis Barbosa. São Paulo, Melhoramentos, I955. . Bênção Paterna. In: . Sonhos d'Ouro: Romance Brazileiro. Rio de Janeiro, José Olympio, I95I. p. 29-38.

. Discursos Parlamentares. Brasília, Câmara dos Deputados, I977. . Diva. Rio de Janeiro, José Olympio, I95I. . Cartas sobre A Confederação dos Tamoios. Rio de Janeiro, Empresa Nacional do Diário, I856.

BARBOSA, Francisco de Assis. José de Alencar Cronista do Primeiro Encilhamento. In: . Achados do Vento. Rio de Janeiro, INL, I958.

BROCA, Brito. Românticos, Ultra-românticos e Pré-românticos. São Paulo, Polis, I979.

COELHO, José Maria Vaz Pinto. Declaração. In: Alencar, José de. Ao Correr da Penna. São Paulo, Tipografia Alemã, I874.

CORREIO MERCANTIL. In: Alencar, José de. Ao Correr da Penna. São Paulo, Tipografia Alemã, I874.

FARIA, João Roberto. O Rio de Janeiro de I854 e I855. In: Alencar, José de. Ao Correr da Pena. Organização de João Roberto Faria. São Paulo, Martins Fontes, 2004, p. XI-XXXIII.

FREIXEIRO, Fábio. Alencar: Os Bastidores e a Posteridade. Rio de Janeiro, Museu Histórico Nacional, I977.

GARRETT, Almeida. Viagens na Minha Terra. Porto, Figueirinhas, I958.

HALLEWELL, Laurence. O Livro no Brasil: Sua História. Tradução de Maria da Penha Villalobos; Lólio Lourenço de Oliveira \& Gerson Geraldo de Souza. São Paulo, Edusp, 2005.

MARCO, Valéria de. O Império da Cortesã. São Paulo, Martins Fontes, I986.

PROENÇA, M. Cavalcanti. José de Alencar na Literatura Brasileira. Rio de Janeiro, Civilização Brasileira, I965. 